\title{
Predicting Virological Failure with Immunological Criteria in First Line ART Patients in a Resource Poor Setting
}

\author{
Krishnaraj Raja ${ }^{1}$, Chockalingam Chandrasekar'1, 0. R. Krishnarajasekhar ${ }^{1}$, \\ Narayanan Ravichandran', Satagopan Kumar', Gurusamy Manoharan'2, \\ Irudayaraj Amala Sharmila1 \\ ${ }^{1}$ Government Hospital of Thoracic Medicine (GHTM), Tambaram Sanatorium, Chennai, India \\ ${ }^{2}$ Consultant, Karpagam Faculty of Medical Sciences and Research and I-TECH, Coimbatore, India \\ Email: krajadr@hotmail.com
}

Received 25 September 2014; revised 20 October 2014; accepted 14 November 2014

Copyright (C) 2014 by authors and Scientific Research Publishing Inc.

This work is licensed under the Creative Commons Attribution International License (CC BY). http://creativecommons.org/licenses/by/4.0/

(c) (7) Open Access

\section{Abstract}

Indroduction: National Aids control Organisation in India implementing National AIDS control program uses WHO's immunological criteria to screen virological failure. Using immunological criteria to detect virological failure has to be assessed. Predicting virological failure with immunological criteria in resource limited settings had low sensitivity. Factors that influence the outcome are studied. Methods: Retrospective study in tertiary care centre for HIV and TB, Chennai, India. Out of 35,044 on ART between January 2008 and September 2009, 452 suspected immunological failures were referred. 273 screened for virological failure. Frequency, sensitivity/specificity, positive/negative predictive values, chi-square test, odds-ratio, independent sample t test for viral load greater than 10,000 and 1000 of each immunological criterion using Epi-Info and SPSS version 19. Results: 172 had virological failure (62.09\%). Average age of failed was 37.33. Single criteria's sensitivity was 60 to 84 for detecting virolological failure. Two or more criteria had specificity 55 to 79. Combination of two or more criteria increased odds ratio for virological failure. Positive predictive value was above 63 for all criteria. PPV was above 80 to the criterion all three positive. Conclusions: ART naive patients with $>\mathbf{9 5 \%}$ adherence the sensitivity of immunological criteria to detect virological failure is three times than earlier studies. Combination of criteria is more significantly associated with virological failure. Odds ratio doubled for two or more combination of criteria. Immunological criteria is affordable/acceptable for screening virological failure, with adherence $>\mathbf{9 5 \%}$ and longer the duration of ART.

\section{Keywords}

ART, Immunological Failure, Virological Failue, Immunological Criteria, Resource Limited 


\section{Settings}

\section{Introduction}

National AIDS control organization (NACO) initiated ART program in India on $1^{\text {st }}$ April 2004 [1]. With intensification of program second line ART program was started in January 2008 [2]. Patients on ART are followed for treatment failure with clinical, immunological and virological criteria. Viral load test is the most sensitive and earliest test to detect treatment failure [3] and virological failure. WHO recommends viral load every 6 months for recognizing treatment failure wherever it is affordable and available. Follow up of patients on ART in developed countries is done by viral load every 3 to 6 months. If the viral load crosses 1000 copies $/ \mathrm{ml}$ virological failure is diagnosed. Following the virological failure, a genotypic resistance test is done and the drugs in the first line ART regimen is changed [4] as per drug resistance pattern. The cost of viral load testing and genotypic resistance studies together is Rupees 8000 per patient. In India, if all 418,062 patients who are on ART in NACO program have to be followed up by viral load every 6 months the cost per year will be more than 2 billions of rupees. Due to high costs of viral load tests, the program has adopted immunological criteria for assessing first line ART failure as per guidelines from WHO for resource limited settings [5].

WHO recommends CD4 count every six months for patients on first line ART and it is available in all ART centres. The CD4 machines are cheaper and are available in ART centres in India. The logistic support for CD4 machines in the program is defined and maintained as per (SOP) standard operative procedures.

The immunological criteria for suspecting treatment failure are

1) CD4 count falling below baseline levels;

2) CD4 count falling more than $50 \%$ of peak value of CD4 count;

3) CD4 count persistently below 100.

If any one of the criteria is present, the virologcal failure is suspected and viral load is done as a targeted viral load in Centres of Excellence (COE) and ARTPLUS centres all over India. SACEP (State AIDS Clinical Expert Panel) were constituted in the COE's and ART PLUS centres. This is a panel of doctors, who study the records and examine ART patients with immunological criteria and advise viral load test to confirm virological failure. During the study period, the criteria of more than 10,000 viral copies/ML is the cut off value and start second line ART to these patients (Now as on date the criteria of 1000 copies/ml of viral load is enough for starting second line drugs).

This SACEP is a new concept which is empowered to do viral load for patients with first line failure and decide to start second line. Earlier experience in other countries which used all drugs for first line and repeated substitution without supervision of drugs resulted few options for second line and resulted in poor ART response to treatment once first line fails. In order to avoid this, SACEP was created and the treatment failure was monitored by this panel. With fixed first line regimens and fixed second line regimens and expert opinion for substitution and switching the drugs in this program will keep the drug options open for even third line.

Disadvantage of using only immunological criteria without virological assessment is 1) it is not a sensitive predictor of virological failure and 2) it may result in late switching to second line therapy. In India Zidovudine based regimen is used as first line ART. The late switching may result in poor response to Tenofovir based regimen which is used for second line in India due to accumulating thymidine associated mutations-TAM's. Many studies from Africa and Thailand [6]-[8], only 8\% to $40 \%$ of individuals who present with evidence of immunological failure had virological failure and resulted in unnecessary switches to second-line ART.

This study will guide us to evaluate the national program and WHO guidelines for resource limited settings which recommend immunological criteria for screening treatment failure.

\section{Methods}

It is a retrospective cross sectional study in Government tertiary care centre for HIV and TB, Tambaram, Tamilnadu, India. The electronic records from January 2008 to September 2009 of all patients referred from Tamilnadu state in India with suspected immunological failure were studied. During the study period 35,044 patients were on ART in 36 ART centres in Tamilnadu, India. 452 patients with suspected immunological failure 
were referred to SACEP, of this study centre which was the only referral centre for all the cases in Tamilnadu, India.

Inclusion criteria:

1) Patients with more than $95 \%$ adherence to treatment for last two years.

2) ART naïve patients

Exclusion criteria:

1) Patients with poor adherence,

2) Patients who had ART before registering in the national program.

CD4 count was tested in standardized cell counter machines in all ART centres for all the patients in Tamilnadu, India. The quality assurance for the CD4 count test is monitored by NACO lab services division. The viral load was done in National institute of tuberculosis research, Chennai for all these patients after the approval of SACEP.

From the electronic data of the patients data was collected and tabulated. The data was analyzed for viral load more than 10,000 copies/ml (NACO guidelines) and 1000 copies/ml as cut off for virological failure. The frequency of criteria and its relationship to virological failure with odds ratio and sensitivity and specificity of each criteria and combination of two criteria were studied to deduct virological failure and compared with previous studies in the world. To collect the retrospective data, ethical committee approval of the institution was sought and was approved by the committee [9] by the rule of Helsinki ethical declaration 2008, section B, rule 25.

\section{Results}

452 patients were referred to SACEP committee during the study period with suspected immunological failure from all over the state out of 35044 patients on ART by the ART centres. 273 were screened based on the inclusion criteria for viral load by SACEP committee. The mean age of the sample population was 37.33 years. Among them 226 (82.8\%) were men and 47 (17.2\%) were women. Out of 273 patients screened, 172 (63\%) had virological failure if viral load of more than 10,000 copes $/ \mathrm{ml}$ is taken as cut off. Among these 154 were males (89.4\%) and the rest were $(10.6 \%)$ were females $(\mathrm{P}=0.0001)$. Duration of ART in patients with virological failure is 2.66 years per 100 patient years (males 2.63 and females 2.94 patient years).

190 (69\%) had virological failure if viral load of more than 1000 copes/ml is taken as cut off. Among these 168 were males (88.4\%) and the rest were $(11.6 \%)$ were females $(\mathrm{P}=0.0001)$.

101 patients showed immunological and virological discordance (37\%). 72 males (71.3\%) and 29 females (28.7\%) were with immunological and virological discordance with $P$ value of 0.002 . The mean age of these patients was 37 years. The duration of ART treatment of discordance patients is 2.73 hundred patient years with P value 0.06 .

179 patients out of 452 were left out because of exclusion and inclusion criteria. There was no bias in rejecting these patients by any means like difference in age, sex and duration of ART by the SACEP members who had no conflicting interests in these patients.

Table 1 shows the frequency of each criterion, frequency of each criterion with virological failure, frequency and percentage of concordance and discordance of virological failure for each criteria. All the above variables were tabulated for viral load $>1000$ copies/ml (as per international guidelines) and $>10,000$ copies/ml (as per NACO guidelines). CD4 count falling more than $50 \%$ of peak value had the highest frequency. Percentage of

Table 1. Frequency of criteria and virological and immunological failure-concordance and discordance.

\begin{tabular}{|c|c|c|c|c|c|c|c|c|c|c|}
\hline \multirow{2}{*}{$\begin{array}{c}\text { Immunological } \\
\text { Criteria }\end{array}$} & \multirow[b]{2}{*}{ Frequency } & \multirow[b]{2}{*}{ Percentage } & \multicolumn{2}{|c|}{$\begin{array}{c}\text { Frequency of } \\
\text { virological failure }\end{array}$} & \multicolumn{2}{|c|}{$\begin{array}{c}\text { Percentage of } \\
\text { virological failure }\end{array}$} & \multicolumn{2}{|c|}{$\begin{array}{l}\text { Frequency of } \\
\text { discordance }\end{array}$} & \multicolumn{2}{|c|}{$\begin{array}{l}\text { Percentage of } \\
\text { discordance }\end{array}$} \\
\hline & & & $\begin{array}{c}>10,000 \\
\text { VL } \\
\text { copies/ml }\end{array}$ & $\begin{array}{l}>1000 \mathrm{VL} \\
\text { copies/ml }\end{array}$ & $\begin{array}{c}>10,000 \\
\text { VL } \\
\text { copies/ml }\end{array}$ & $\begin{array}{l}>1000 \mathrm{VL} \\
\text { copies } / \mathrm{ml}\end{array}$ & $\begin{array}{c}>10,000 \\
\text { VL } \\
\text { copies/ml }\end{array}$ & $\begin{array}{l}>1000 \mathrm{VL} \\
\text { Copies/ml }\end{array}$ & $\begin{array}{c}>10,000 \\
\text { VL } \\
\text { Copies/ml }\end{array}$ & $\begin{array}{l}>1000 \mathrm{VL} \\
\text { copies/ml }\end{array}$ \\
\hline $\begin{array}{l}\text { CD4 count } \\
\text { below base }\end{array}$ & 155 & 56.77 & 105 & 111 & $67.7 \%$ & $71.6 \%$ & 50 & 44 & $32.2 \%$ & $28 \%$ \\
\hline $\begin{array}{l}\text { CD4 count } \\
50 \% \text { fall }\end{array}$ & 216 & 79.1 & 146 & 154 & $67.69 \%$ & $71.2 \%$ & 70 & 62 & $32.4 \%$ & $28.7 \%$ \\
\hline $\begin{array}{l}\text { CD4 count } \\
<100\end{array}$ & 163 & 59.7 & 116 & 122 & $71.1 \%$ & $74.8 \%$ & 47 & 41 & $28.8 \%$ & $25.1 \%$ \\
\hline
\end{tabular}


concordance of virological and immunological failure is highest in CD4 count persistently below 100. Percentage of discordance of virological and immunological failure in CD4 count falling more than 50\% criterion.

Table 2 shows for each criterion the odds ratio and $\mathrm{P}$ value calculated using Chi-square method when viral load was more than 1000 copies/ml or 10,000 copies/ml. CD4 count persistently below 100 had more than two odds to have virological failure with significant $P$ values for both 1000 and 10,000 copies/ml of viral load. CD4 COUNT falling $50 \%$ of peak value had more than two odds to have virological failure with significant P-value for viral load > 10,000 copies/ml. CD4 count falling below baseline was not associated significantly for virological failure.

Table 3 shows for each two criteria the odds ratio and $\mathrm{P}$ value calculated using Chi-square method when viral load was $>1000$ or 10,000 copies $/ \mathrm{ml}$. The odds increased to more than 3 times in combining 2 criteria CD4 count persistently below 100 and CD4 count below baseline, for viral load more than 10,000 copies/ml and more than 2 times for more than 1000 copies/ml with significant $\mathrm{P}$ value.

Table 4 shows the table with criteria taken as a test and virological failure as outcome. The validity of the criterion is done by sensitivity and specificity. The sensitivity was highest (84.88\%) in CD4 count falling > 50\% of peak value. Combination of two criteria has higher specificity for virological failure. Combination of criteria CD4 count persistently below 100 and CD4 count below baseline has highest specificity (80.2\%).

It was observed from Table 4 that the positive predictive value for Viral load $>1000 \mathrm{copies} / \mathrm{ml}$ is higher when compared to viral load $>10,000$ copes/ml in all immunological criteria. The PPV was above 63 for all criteria.

Table 5 shows multi-nominal logistic regression of all three criteria with odds ratio and the P-value for virological failure. It shows that the criteria's CD4 count persistently below 100 and CD4 count falling 50\% of peak value were significantly associated with virological failure than the CD4 count below baseline criterion.

Table 2. Comparison of each immunological criterion with viral load greater than 10,000 copies/ml and 1000 copies/ml.

\begin{tabular}{|c|c|c|c|c|}
\hline & \multicolumn{2}{|c|}{ Viral Load $>10,000$ copies/ml } & \multirow{2}{*}{ P value ${ }^{*}$} & \multirow{2}{*}{ Odds ratio } \\
\hline & Yes & No & & \\
\hline \multicolumn{5}{|c|}{ CD4 count persistently below 100} \\
\hline Yes & 116 & 47 & \multirow[t]{2}{*}{0.000} & \multirow[t]{2}{*}{2.379} \\
\hline No & 55 & 46 & & \\
\hline \multicolumn{5}{|c|}{ CD4 count below baseline } \\
\hline Yes & 105 & 50 & \multirow[t]{2}{*}{0.091} & \multirow[t]{2}{*}{1.652} \\
\hline No & 67 & 51 & & \\
\hline \multicolumn{5}{|c|}{ CD4 count falling $50 \%$ of peak value } \\
\hline Yes & 146 & 70 & \multirow[t]{2}{*}{0.003} & \multirow[t]{2}{*}{2.486} \\
\hline No & 26 & 31 & & \\
\hline & \multicolumn{2}{|c|}{ Viral Load > 1000 copies/ml } & \multirow{2}{*}{ P value ${ }^{*}$} & \multirow{2}{*}{ Odds ratio } \\
\hline & Yes & No & & \\
\hline \multicolumn{5}{|c|}{ CD4 count persistently below 100} \\
\hline Yes & 122 & 41 & \multirow[t]{2}{*}{0.02} & \multirow[t]{2}{*}{1.83} \\
\hline No & 68 & 42 & & \\
\hline \multicolumn{5}{|c|}{ CD4count below baseline } \\
\hline Yes & 111 & 44 & \multirow[t]{2}{*}{0.404} & \multirow[t]{2}{*}{1.230} \\
\hline No & 79 & 39 & & \\
\hline \multicolumn{5}{|c|}{ CD4 count falling $50 \%$ of peak value } \\
\hline Yes & 154 & 62 & \multirow[t]{2}{*}{0.233} & \multirow[t]{2}{*}{1.44} \\
\hline No & 36 & 21 & & \\
\hline
\end{tabular}

"P value calculated using Chi square method. 
Table 3. Comparision of the combination of 2 immunological criteria to virological failure when viral load is more than 10,000 copies/ml and more than 1000 copies/ml.

\begin{tabular}{|c|c|c|c|c|}
\hline & \multicolumn{2}{|c|}{ Viral Load > 10,000 copies/ml } & \multirow{2}{*}{ P value } & \multirow{2}{*}{ Odds ratio } \\
\hline & Yes & No & & \\
\hline \multicolumn{5}{|c|}{ CD4 count persistently below 100 \& CD4 count below baseline } \\
\hline Yes & 77 & 20 & 0.000 & 3.160 \\
\hline No & 95 & 81 & & \\
\hline \multicolumn{5}{|c|}{ CD4count below baseline \& CD4 count falling $50 \%$ of peak value } \\
\hline Yes & 83 & 42 & 0.306 & 1.294 \\
\hline No & 89 & 59 & & \\
\hline \multicolumn{5}{|c|}{ CD4count falling 50\% of peak value \& CD4 count persistently below 100} \\
\hline Yes & 79 & 44 & \multirow[t]{2}{*}{0.738} & \multirow[t]{2}{*}{1.088} \\
\hline No & 93 & 57 & & \\
\hline & \multicolumn{2}{|c|}{ Viral Load > 1000 copies/ml } & \multirow{2}{*}{ P value $^{*}$} & \multirow{2}{*}{ Odds ratio } \\
\hline & Yes & No & & \\
\hline \multicolumn{5}{|c|}{ CD4 count persistently below 100 \& CD4 count below baseline } \\
\hline Yes & 79 & 19 & 0.003 & 2.397 \\
\hline No & 111 & 64 & & \\
\hline \multicolumn{5}{|c|}{ CD4 count below baseline \& CD4 count falling 50\% of peak value } \\
\hline Yes & 92 & 49 & \multirow[t]{2}{*}{0.256} & \multirow[t]{2}{*}{1.353} \\
\hline No & 98 & 34 & & \\
\hline \multicolumn{5}{|c|}{ CD4 count falling $50 \%$ of peak value \& CD4 count persistently below 100} \\
\hline Yes & 88 & 36 & \multirow[t]{2}{*}{0.653} & \multirow[t]{2}{*}{1.126} \\
\hline No & 102 & 47 & & \\
\hline
\end{tabular}

Table 4. PPV, NPV, sensitivity and specificity of various criteria VL-Viral Load.

\begin{tabular}{|c|c|c|c|c|c|c|}
\hline & $\mathrm{TP}$ & $\mathrm{TN}$ & Sensitivity & Specificity & PPV & NPV \\
\hline \multicolumn{7}{|c|}{ For VL > 10,000 copies/ml } \\
\hline CD4 count persistently below 100 & 116 & 55 & 68.02 & 53.46 & 71.16 & 53.46 \\
\hline CD4 count below baseline & 105 & 51 & 61.05 & 50.5 & 67.74 & 43.21 \\
\hline CD4 count falling $50 \%$ of peak value & 146 & 31 & 84.88 & 30.39 & 67.28 & 54.38 \\
\hline $\begin{array}{l}\text { CD4 count persistently below } 100 \& \\
\text { CD4 count below baseline }\end{array}$ & 77 & 81 & 44.77 & 80.2 & 79.38 & 46.23 \\
\hline $\begin{array}{c}\text { CD4 count below baseline \& } \\
\text { CD4 count falling } 50 \% \text { of peak value }\end{array}$ & 83 & 59 & 48.23 & 58.44 & 66.47 & 39.83 \\
\hline $\begin{array}{l}\text { CD4 count falling } 50 \% \text { of peak value \& } \\
\text { CD4 count persistently below } 100\end{array}$ & 79 & 57 & 45.93 & 56.44 & 64.38 & 38.00 \\
\hline \multicolumn{7}{|c|}{ For VL > 1000 copies/ml } \\
\hline CD4 count persistently below 100 & 122 & 42 & 64.21 & 50.60 & 74.82 & 38.18 \\
\hline CD4 count below baseline & 111 & 44 & 58.11 & 46.98 & 71.61 & 33.05 \\
\hline CD4 count falling $50 \%$ of peak value & 154 & 21 & 81.05 & 25.30 & 71.35 & 36.84 \\
\hline $\begin{array}{l}\text { CD4 count persistently below } 100 \& \\
\text { CD4 count below baseline }\end{array}$ & 79 & 64 & 41.57 & 71.10 & 80.61 & 36.57 \\
\hline $\begin{array}{c}\text { CD4 count below baseline \& } \\
\text { CD4 count falling } 50 \% \text { of peak value }\end{array}$ & 92 & 34 & 48.42 & 40.96 & 65.25 & 25.76 \\
\hline $\begin{array}{l}\text { CD4 count falling } 50 \% \text { of peak value \& } \\
\text { CD } 4 \text { count persistently below } 100\end{array}$ & 88 & 47 & 46.31 & 56.62 & 70.96 & 31.54 \\
\hline
\end{tabular}


Table 5. Multi-nominal logistic regression of the three criteria with high odds.

\begin{tabular}{cccc}
\hline Viral load & Immunological criteria with high odds and significant P values & OR & P value \\
\hline & CD4 count below baseline & 1.652 & 0.147 \\
$\mathrm{VL}>10,000$ copes $/ \mathrm{ml}$ & CD4 count persistently below 100 & 2.445 & 0.000 \\
& CD4 count falling 50\% of peak value & 2.466 & 0.001 \\
$\mathrm{VL}>1000$ copies $/ \mathrm{ml}$ & CD4 count below baseline & 1.23 & 0.590 \\
& CD4 count persistently below 100 & 1.83 & 0.001 \\
\hline
\end{tabular}

The same association is also noted for viral load more than 1000 copies $/ \mathrm{ml}$ also.

From Table 6 showing independent $\mathrm{T}$ sample test it is seen that for viral load $>10,000$ copies $/ \mathrm{ml}$ and $>1000$ copies/ml the age has shown a significant association but the significance of duration of treatment was seen only in viral load greater than 10,000 and not 1000 copies/ml. However a significant association was seen for immunological criteria for both age and duration of treatment $(\mathrm{P}=0.000)$.

\section{Discussion}

The expected failure for first line ART is 5\% per year [10]. In United States of America the treatment failure rates were 3.5\% in 1990 and has raised to 12\% in 2002 [8]. In B.J Medical College, Centre of excellence approved by NACO, Ahmedabad, India [11] where NACO guidelines followed the immunological failure was $2.3 \%$ and the virological failure among them was $1.70 \%$ of the 5847 patients. An Indian editorial [8] suggested at the end of 24 months the virological failure was quoted as $15 \%$ to $18 \%$ in India. In a study [12] at GHTM, Tambaram, Chennai, India the estimated treatment failure was 3.9\% in 1300 patients on first line therapy. It also predicts that 51,000 patients need second line by the end of 2010 in NACO program.

The follow up of patients with ART in various countries without uniform guidelines on clinical, immunological and virological criteria had resulted in early or late switching for second line drugs [13]. The outcomes were either positive or negative. Most of them concluded low sensitivity of immunological criteria to predict virological failure.

In Malawi study [14] of patients on ART were switched to second line based on clinical criteria and immunological criteria. Among them when correlated with viral load 57\% with clinical criteria and $30 \%$ with immunological criteria were wrong. If the duration is less than 2 years and CD4 more than $200 \mathrm{cells} / \mathrm{ml}$ resulted in poor sensitivity in this study. In western Kenyan study [15] at least 58\% of patients were switched to second line without virological failure with fall in CD4 count of 25\% in 6 months and CD4\% falling from $19 \%$ to $25 \%$. The immunological criteria were concluded as less sensitive. The usefulness of clinical and immunological criteria was doubtful by these studies [16].

In this tertiary care centre for HIV and TB, Tambaram study at the end of September 2009 out of 37,386 patients [11] registered by ART centers in Tamilnadu, 452 (1.2\%) from all over Tamilnadu were referred with suspected immunological failure. The reasons for the low rates of referral may be 1) Deaths of many patients without getting ART. 2) Though first line ART was started in 2004, second line was available only from 2008. Many would have died with first line failure. 3) The scaling up of facilities in Tamilnadu was rapid only in the last two or three years. So immunological failure rates may rise to expected levels in near future. 4) Only a few centres which were started early in 2004 like Namakkal, Madurai, Salem Art centres have contributed the bulk of referral during this study.

Only for ART naïve patients with more than 95\% adherence and completed ART for at least 24 months from all ART centres in Tamilnadu SACEP recommended viral load. Out of 273 patients recommended only 172 had virological failure of more than 10,000 copies/ml and 190 had viral load of more than 1000 copies $/ \mathrm{ml}$. (NACO has revised to 1000 copies/ml for switching to second line from 2014). On analyzing 273 patients the frequency of criteria in patients with at least one criterion varied from $58 \%$ to $79 \%$. Any two criteria in $36 \%$ to $46 \%$ patients and 31\% had all 3 criteria's.

The CD4 count falling below baseline had the least frequency. The reason is many patients with very low 
Table 6. Independent T sample tests-comparison of age and duration of treatment with virological and immunological failure.

\begin{tabular}{|c|c|c|c|c|c|c|}
\hline \multicolumn{2}{|c|}{$\mathrm{VL}>10,000$ copies $/ \mathrm{ml}$} & $\mathrm{N}$ & Mean & Std. Deviation & Std. Error Mean & P Value \\
\hline \multirow{2}{*}{ Age } & No & 101 & 36.80 & 7.948 & 0.787 & 0.025 \\
\hline & Yes & 172 & 38.05 & 6.749 & 0.515 & \\
\hline \multirow{2}{*}{ Duration of month } & No & 101 & 32.64 & 12.57 & 1.245 & \\
\hline & Yes & 172 & 32.05 & 10.89 & 0.830 & 0.049 \\
\hline \multicolumn{2}{|c|}{$\mathrm{VL}>1000$ copies/ml } & $\mathrm{N}$ & Mean & Std. Deviation & Std. Error Mean & $P$ Value \\
\hline \multirow{2}{*}{ Age } & No & 83 & 37.40 & 8.164 & 0.896 & 0.018 \\
\hline & Yes & 190 & 37.67 & 6.805 & 0.492 & \\
\hline \multirow{2}{*}{ Duration of month } & No & 83 & 32.67 & 12.494 & 1.371 & 0.154 \\
\hline & Yes & 190 & 32.10 & 11.110 & 0.804 & \\
\hline \multicolumn{2}{|c|}{ Immunological failure } & $\mathrm{N}$ & Mean & Std. Deviation & Std. Error Mean & P Value \\
\hline \multicolumn{2}{|l|}{ Age } & 273 & 37.59 & 7.229 & 0.437 & 0.000 \\
\hline \multicolumn{2}{|c|}{ Duration of month } & 273 & 32.27 & 11.52 & 0.696 & 0.000 \\
\hline
\end{tabular}

CD4 count were initiated on ART for the first time. So the chance of CD4 count falling below baseline is very low. The CD4 count falling more than $50 \%$ had the highest frequency. Again many patients would have good immunological response and when they fail first line this fall of 50\% were more often seen than other criteria.

In (Table 4) the sensitivity of each criterion is not altered significantly when virological failure was considered by 10,000 copies/ml or 1000 copies/ml. Sensitivity varied from 54 to 84 with any one criterion. CD4 count below baseline had the lowest sensitivity of 60 , while $50 \%$ fall of CD4 count from peak value had highest of 84 . Specificity varied from 27 to 54 . CD4 count persistently below 100 had the highest specificity of 54 while 50\% fall of CD4 count from peak value had lowest 30.

In Malawi study in Africa the sensitivity was low 12 to 17 while comparing this study [14]. The specificity was very high $97 \%$ for the immunological criteria in that study. In this Tambaram study the sensitivity is five times more than what it was in African study. The specificity was nearly half of the African study. So this study has shown better sensitivity of predicting virological failure with the immunological criteria.

The reasons for higher sensitivity in this study while comparing these African studies is the immunological criteria was used and treatment failure was identified at the end of two years with more than $95 \%$ adherence. The relationship of CD4 count of more than $200 \mathrm{cell} / \mathrm{ml}$ with virologcal failure was not studied in this study.

The duration in this Tambaram study was for 21 months with all patients having more than $95 \%$ adherence by weekly sitting of SACEP and 2.66 hundred patient years. So high duration of ART treatment with high adherence might have increased the sensitivity of the criteria to detect virological failure with statistically significant ( $\mathrm{P}$ value -0.04 ) when viral load cut off was $>10,000$ copies/ml.

The combination of two or more criteria had high specificity for virological failure. The high specificity of combination of criteria is due to the high sensitivity of complimentary criteria that left out (for example if CD4 below baseline and CD4 persistently below 100 is combined criteria then CD4 falling more than 50\% criterion is complimentary criteria). If CD4 count falling below $50 \%$ of peak value had high sensitivity 84 , the combination of other two criteria namely CD4 count below base line and CD4 count persistently below 100 had low sensitivity of 44 . We also note high specificity of 79 for the combination of CD4 count below base line and CD4 count persistently below 100 .

Chi-square tests show single criteria and virological failure were significantly associated with virological failure whether viral load is 10,000 copies/ml or 1000 copies/ml except for criteria of CD4 count falling below base line ( $\mathrm{P}$ values 0.09 and 0.404 respectively). This may be due to the frequency of occurrence of this criteria is less than $50 \%$ of the screened patients. If viral load of more than 1000 copies $/ \mathrm{ml}$ is considered CD4 count falling more than $50 \%$ is not significantly associated ( $\mathrm{P}$ value 0.23 ). When combinations of criteria is studied all 
the combinations are associated significantly except the combination of CD4 count falling more than 50\% from peak value and CD4 count falling below base line with more than 1000 copies/ml of viral load (P value 0.256 ). Chi-square tests were not done in previous studies. Here this comparison is done only to show the association of the criteria and virological failure and not as a causative or predicting factor.

The odds ratio for 50\% fall from peak value and persistently below 100 was two and half times whereas for below baseline it was only around two times. Any way the odds to get virological failure are more than one in all the criteria. The odds ratio for combination of criteria is the highest (three times) with $50 \%$ fall and persistently below 100 .

The main limitation of this study is no control groups who do not have the immunological criteria but have virological failure. If this had been studied then the value of sensitivity and specificity and odds ratio etc would have been reflected more correctly. Since the study was done in a public health programmatic set up it was not done.

\section{Conclusion}

In a public health program still WHO's immunological criteria can be used to screen the patients for treatment failure with $60 \%$ to $80 \%$ sensitivity in resource limited setting. The longer the duration of ART and more than $95 \%$ adherence for longer duration will result in better sensitivity. So in resource limited setting, the usage of WHO’s immunological criteria may be more cost effective than other methods.

\section{References}

[1] NACO (2011) Patients Alive and on ART.

[2] (2009) Annual Report. Department of AIDS Control, Ministry of Health and Family Welfare.

[3] Hosseinipour, M., van Oosterhout, J., Weigel, R., Mzigangira, D., Saukila, N., Mhango, B., et al., The SAFEST 2 Study Team (2009) Validating Clinical and Immunological Definitions of Antiretroviral Treatment Failure in Malawi. The 4th IAS Conference on HIV Pathogenesis, Treatment and Prevention, Sydney, 22-25 July 2009.

[4] Kumarasamy, N. and Ganguly, M. (2009) Editorial. Indian Journal of Medical Research, 130, 669-670.

[5] NACO (2008) Operational Guidelines for First Line ART Program. Ministry of Health and Family Welfare.

[6] Sungkanuparph, S., Manosuthi, W., Kiertiburanakul, S., Piyavong, B., Chumpathat, N. and Chantratita, W. (2007) Options for a Second-Line Antiretroviral Regimen for HIV Type 1-Infected Patients Whose Initial Regimen of a FixedDose Combination of Stavudine, Lamivudine, and Nevirapine Fails. Clinical Infectious Diseases, 44, 447-452. http://dx.doi.org/10.1086/510745

[7] DART Virology Group and Trial Team (2006) Virological Response to a Triple Nucleoside/Nucleotide Analogue Regimen over 48 Weeks in HIV-1-Infected Adults in Africa. AIDS, 20, 1391-1399. http://dx.doi.org/10.1097/01.aids.0000233572.59522.45

[8] Hosseinipour, M.C., van Oosterhout, J.J., Weigel, R., Phiri, S., Kamwendo, D., Parkin, N., et al. (2009) The Public Health Approach to Identify Antiretroviral Therapy Failure: High-Level Nucleoside Reverse Transcriptase Inhibitor Resistance among Malawians Failing First-Line Antiretroviral Therapy. AIDS, 23, 1127-1134. http://dx.doi.org/10.1097/QAD.0b013e32832ac34e

[9] (2008) Helsinki Ethical Declaration. Section B.

[10] (2008) The World Health Organization’s Global Strategy for Prevention and Assessment of HIV Drug Resistance. Antiviral Therapy, 13, 1-13.

[11] Amin, B., Derasari, U., Nihalani, U., Purohit, H., Shevkani, M., Prajapati, S., et al. (2010) ART Center B J Medical College, Ahmedabad, India-Outcome of First Line Antiretroviral Therapy (Art) with Respect to Treatment Failure at ART CENTRE, B. J. Medical College, Civil Hospital. Ahmedabad-Retrovirology, 7, 49.

[12] Rajasekaran, S., Jeyaseelan, L., Vijila, S., Gomathi, C. and Raja, K. (2007) Predictors of Failure of First-Line Antiretroviral Therapy in HIV-Infected Adults: Indian Experience. (GHTM), AIDS, 21, S47-S53. http://dx.doi.org/10.1097/01.aids.0000279706.24428.78

[13] (2008) Guidelines for the Use of Antiretroviral Agents in HIV-1-Infected Adults and Adolescents. Office of AIDS Research, NIH-A Working Group of the OARAC.

[14] Van Oosterhout, J.J., Brown, L., Weigel, R., Kumwenda, J.J., Mzinganjira, D., Saukila, N., et al. (2009) Diagnosis of Antiretroviral Therapy Failure in Malawi: Poor Performance of Clinical and Immunological WHO Criteria. Tropical Medicine \& International Health, 14, 856-861. http://dx.doi.org/10.1111/j.1365-3156.2009.02309.x 
[15] Kantor, R., Diero, L., Delong, A., Kamle, L., Muyonga, S., Mambo, F., Walumbe, E., et al. (2009) Misclassification of First-Line Antiretroviral Treatment Failure Based on Immunological Monitoring of HIV Infection in Resource-Limited Settings. Clinical Infectious Diseases, 49, 454-462. http://dx.doi.org/10.1086/600396

[16] Hosseinpour, M.C. and Schechter, M. (2010) Monitoring Antiretroviral Therapy in Resource-Limited Setting; Balancing Clinical Care, Technology and Human Resource. Current HIV/AIDS Report. 
Scientific Research Publishing (SCIRP) is one of the largest Open Access journal publishers. It is currently publishing more than 200 open access, online, peer-reviewed journals covering a wide range of academic disciplines. SCIRP serves the worldwide academic communities and contributes to the progress and application of science with its publication.

Other selected journals from SCIRP are listed as below. Submit your manuscript to us via either submit@scirp.org or Online Submission Portal.
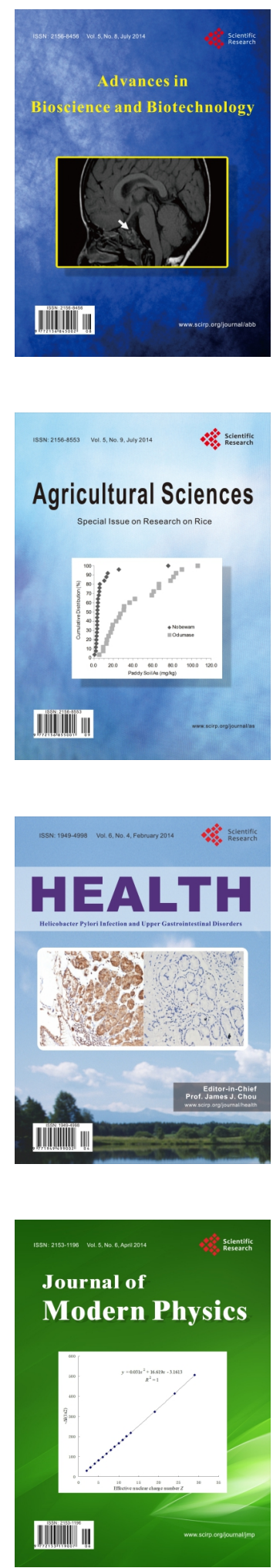
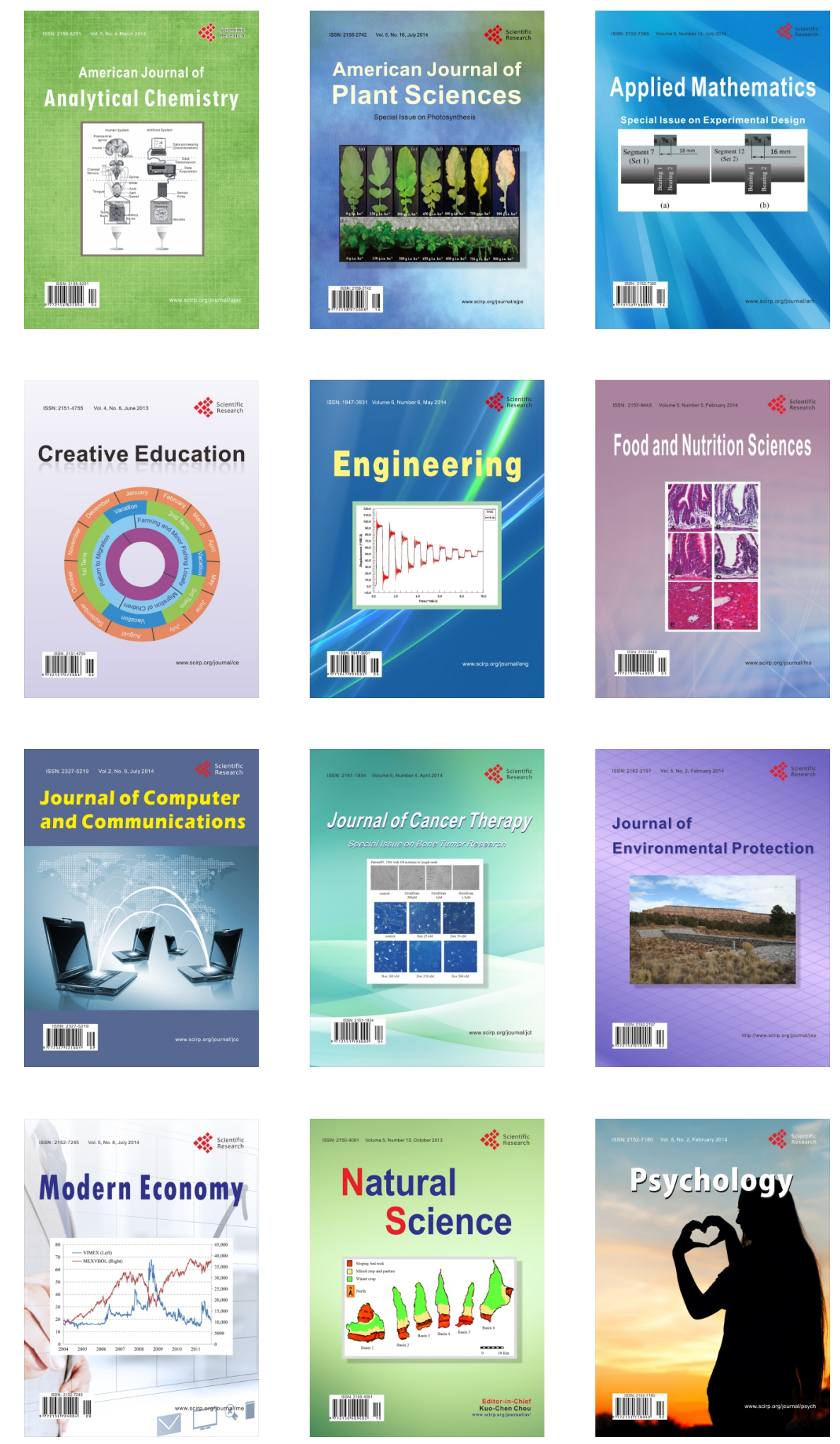